\title{
CORRELATION BETWEEN PROTHROMBIN TIME AND SERUM FERRITIN LEVEL IN THALASSAEMIA PATIENTS
}

\author{
NASIMA SULTANA ${ }^{1}$, SALMA SADIYA ${ }^{2}$
}

Associate professor \& Head, Dept. of Biochemistry, Dhaka Medical College, Dhaka ${ }^{1}$, Assistant Professor, Dept. of Pathology, Dhaka Shishu Hospital, Dhaka²

\begin{abstract}
Thalassaemia is the most common hereditary disorder in the world including Bangladesh. Beta thalassaemia major and $\mathrm{Hb}-\mathrm{E}$ thalassaemia both are common in our country. Iron overload causes most of the mortality and morbidity associated with thalassaemia. To assess the iron overload and liver function a cross sectional comparative study carried out in the Department of Biochemistry, Dhaka Medical College, Dhaka in collaboration with Thalassaemia Center and Department of Pathology, Dhaka Shishu Hospital, Dhaka during the period of July 2006 to June 2007. The study was carried out with the patients who visited regularly in Dhaka Shishu Hospital Thalassaemia Centre (DSHTC) and have multiple transfusions (more than five) and the age more than 2 years. To compare the state of liver function individuals' normal healthy persons were also included. Total 70 subjects were included in this study. The study subjects were distributed into two groups, the group - A (cases) and group - B (healthy controls). Group - A consisted of 40 thalassaemia patients and group $-B$ consisted of 30 healthy individuals. According to the major types of thalassaemia present in our country, group $-A$ again divided into two, group - Al patients of â-thalassaemia major included 12 patients and group - All patients of Hemoglobin $E$ âthalassaemia included 28 patients. Prothrombin time. A statistically significant mean difference of prothrombin time was found indicating patients of thalassaemia had higher prothrombin time than normal healthy individuals $(p<0.001)$. A statistically insignificant mean difference of prothrombin time was found indicating group -Al and patients All had no difference in prothrombin time $(p>0.05)$. Pearson's Correlation between prothrombin time of patients in seconds and serum ferritin of in $\mathrm{ng} / \mathrm{ml}$ had studied in two ways as a whole correlation between prothrombin time of all the patients in second and serum ferritin of patients in $\mathrm{ng} / \mathrm{ml}$ had $r$ value 0.39 was statistical significant $(P<0.05)$. On the other side correlation between prothrombin time of the patients of Group $\mathrm{Al}$ in second and serum ferritin of same patients in $\mathrm{ng} / \mathrm{ml}$ had $r$ value of 0.17 was signficant $(P<0.05)$. But correlation between prothrombin time of the patients of group $-1 /$ in second and serum ferritin of same patients in $\mathrm{ng} / \mathrm{ml}$ had $r$ value 0.46 was statistically significant ( $p$ $<0.05)$. A statistically significant mean difference of ferritin was found indicating ferritin of group Al had higher level of ferritin than group All. ( $p<0.05)$.
\end{abstract}

Key words: Thalassaemia, Prothrombin time, Serum ferritin

(Bangladesh J Physiol Pharmacol 2010; 26(1\&2) : 10-15)

\section{INTRODUCTION}

Thalassaemia is the most common hereditary disorder in the world including Bangladesh. Thalassaemia is a major health problem all over the world but this is particularly in the developing countries where the resources are limited $^{1}$. Thalassaemia is characterized by reduced production of normal hemoglobin due to absence or decrease synthesis of

Address of Correspondence: Dr. Nasima Sultana, Associate professor \& Head, Dept. of Biochemistry, Dhaka Medical College, Dhaka, Phone: 01715992188, Email: snasima62@yahoo.com one or more type of polypeptide chain ${ }^{2}$. Hemoglobinopathies are characterized by the production of structurally defective hemoglobin due to abnormalities in the formation of globin moiety of the molecule ${ }^{2}$. There are two main classes of thalassaemia called alpha and beta thalassaemia that result from defective alpha and beta chain synthesis respectively. There is rare form in which both beta and delta chain production are reduced, delta-beta thalassaemia, or in which epsilon, gamma, delta and beta chain production are defective, epsilongamma- delta-beta thalassaemia ${ }^{3}$. Alpha thalassaemia 
is characterized by reduced or suppressed production of á-globin chain ${ }^{4}$. It is found most commonly in individuals with an ethnic background of Southeast Asia, Southern China, the Middle East, India, Africa and the Mediterranean. Clinically there are four á-thalassaemia syndromes. These occur because of inheritance of molecular mutations affecting the output of one, two, three or four of the -globin genes ${ }^{5}$. Beta thalassaemia is caused by decreased or suppressed production of $\beta$-globin chain. It is the most important type of thalassaemia, because it is common and usually produce severe anemia in homozygous and heterozygous status ${ }^{2}$. Clinically $\beta$ thalassaemias are heterogeneous group of disorders and three types, $\beta$-thalasaemia minor or â-thalassaemia trait, â-thalassaemia intermedia and â-thalassaemia major. Beta thalassaemias occur widely in a broad belt, ranging from the Mediterranean and parts of north and West Africa through the Middle East and Indian subcontinent to South East Asia ${ }^{6}$. Hb-E $\beta$-thalassaemia is the commonest severe form of thalassaemia in South East Asia and part of Indian subcontinent. It is the most common form of thalassaemia in Bangladesh. Hb-E is ineffectively synthesized and hence, when it inherited together with â-thalassaemia there is marked deficiency of â-chain production. The clinical and hematological changes are variable ${ }^{6}$. Clinically it is again divided into mild, moderate and severe form. Severe form of this type of thalassaemia shows clinical manifestations as âthalassaemia major. With the better treatment, survival of the patients with these disorders increase represents one of the most dramatic alteration in morbidity and mortality associated with a genetic disease in 19th century and the subjects are being constantly reviewed ${ }^{7}$.

Beta thalassaemia major and $\mathrm{Hb}-\mathrm{E}$ thalassaemia both are common in our country. A conservative world health report has estimated that three percent are carrier of â-thalassaemia and four percent are carriers of $\mathrm{Hb}-\mathrm{E}$ â-thalassaemia ${ }^{8}$. A recent study on school children in different district of Bangladesh has shown overall prevalence of â-thalassaemia trait was $4.1 \%$ and $\mathrm{Hb}-\mathrm{E}$ â-thalassaemia was $6.1 \%$. Calculated value of the expected births of â-thalassaemia major annually in our country is 1040 and $\mathrm{Hb}-\mathrm{E} \beta$-thalassaemia is $6443^{9}$. Due to availability of improved health service and diet the death of children from diarrhea, respiratory tract infection and malnutrition has been fallen, more children are now surviving and visiting hospital with hereditary disorders like thalassaemia. Proper management of thalassaemia patient can decrease morbidity and mortality and they can survive with a good quality of life up to third or fourth decade. Children who suffer from this disease need a lifelong repeated blood transfusion to maintain their hemoglobin level around $12 \mathrm{~g} / \mathrm{dl}$, but unfortunately those will cause an accumulation of iron in various tissue accompanied by an increase serum iron level ${ }^{9}$. Iron over load occurs when iron intake is increased over a sustained period of time, either from the transfusion of red cells or because there is increased absorption of iron from digestive tract. Both of these occur in thalassaemia, blood transfusion being the major cause in thalassaemia major and increased iron absorption being more important cause in thalassaemia intermedia. Because there is no mechanism in human to excrete the excess iron, this has to be removed by chelating agent ${ }^{10}$. Iron overload causes most of the mortality and morbidity associate with thalassaemia. Iron deposition occurs in visceral organs mainly in heart, liver and endocrine glands causing tissue damage and ultimately gastrointestinal absorption are contributory. Paradoxically, excess gastrointestinal iron absorption persists despite massive increases in total body iron load. Hepcidin is a small peptide that inhibits iron absorption in the small bowel. Hepcidin levels normally increase when iron stores are elevated. Its levels were found to be inappropriately low in patients with thalassaemia intermedia and thalassaemia major ${ }^{11}$.

The combination of iron overload and increase outpouring of catabolic iron from the reticuloendothelial system overwhelm the iron binding capacity of transferrin, resulting in the emergence of toxic non transferrin bound plasma iron (NTBI). NTBI promotes the formation of free hydroxyl radicals and accelerates the peroxidation of membrane lipids. Both lipid peroxidation and TGF $\beta-1$ expression resulted from iron over load may promote hepatic injury and fibrogenesis ${ }^{12}$. Furthermore âthalassaemia and $\mathrm{Hb}-\mathrm{E} \beta$-thalassaemia patients treated with blood transfusion are also liable to infected with Hepatitis B and Hepatitis C if proper screening is not done which can cause hepatic fibrosis and cirrhosis ${ }^{13}$. So thalassaemia patients must be routinely checked for liver function.

In the condition of iron accumulation and chronic viral hepatitis, there is an increase of serum iron level, transferrin saturation and ferritin level. Ferritin is an intracellular storage iron, which is present mainly in the reticuloendothelial cells. Clinically significant concentration is found in serum and the level of serum ferritin reflects total body iron stores ${ }^{14,15}$. A serum ferritin concentration reflects iron storages in health and also in certain diseases $^{16}$. Ferritin a high molecular weight iron containing protein, acts in human body as an iron storage depot. It is a major iron storage protein of liver, spleen, 
bone marrow and other tissue of the body. Its two major functions are to remove excess iron from cells converting it into a harmless soluble form, and to provide a mobilizable reserve of iron which can be drawn when needed. Most of the ferritin is intracellular but the measurement of circulating serum ferritin reflects the level of the body iron store ${ }^{17,18}$.

To judge the extension of liver cell damage caused by iron accumulation, a very sensitive indicator for liver function, serum bilirubin was assessed. Hyperbilirubinaemia may be found in prehepatic (haemolytic), hepatic, and post hepatic (obstructive).

Thalassaemia patients if treated with proper blood transfusion and chelating therapy they can maintain apparently normal life but for the maintenance of healthy life they should be routinely checked for their liver function, cardiac function and endocrine function.

\section{MATERIALS AND METHODS}

A cross sectional comparative study carried out in the Department of Biochemistry, Dhaka Medical College, Dhaka in collaboration with Thalassaemia Center and Department of Pathology, Dhaka Shishu Hospital, Dhaka during the period of July 2006 to June 2007. The study was carried out with the patients who visited regularly in Dhaka Shishu Hospital Thalassaemia Centre (DSHTC) and have multiple transfusions (more than five) and the age more than 2 years. To compare the state of liver function' normal healthy persons were also included. Total 70 subjects were included in this study. The study subjects were distributed into two groups, the group - A (cases) and group - B (healthy controls). Group - A consisted of 40 thalassaemia patients and group - B consisted of 30 healthy individuals. According to the major types of thalassaemia present in our country, group -A again divided into two, group - $A$, patients of âthalassaemia major included 12 patients and group $A_{\text {II }}$ patients of Hemoglobin E â-thalassaemia included 28 patients. Inclusion and exclusion criteria were considered. The inclusion criteria were a. Diagnosed case of thalassaemia major and hemoglobin $E$ âthalassaemia who have transfused more than five times, b. Age: two years and above, c. Sex: both sexes. Exclusion criteria were a. Below two years, b. Other hemolytic disorders, c. Acute systemic illness and d. Hepatitis B or Hepatitis $C$ positive patients. The patients who fulfill the inclusion and exclusion criteria were selected for the study. After taking informed written consent of all the subjects, necessary information were recorded in a predesigned pre-tested structured questionnaire. The questionnaire included name, age, sex, blood group ,economic status, $\mathrm{Hb}$ electrophoresis report, age of diagnosis, number of transfusion taken, state \& type of chelating therapy, Hepatitis B and Hepatitis C status,
Hepatitis B vaccination status and dietary habit of patients. After that $5 \mathrm{ml}$ of venous blood sample was drawn in a sterile test tube aseptically by venipuncture with sterile disposable syringe. Blood sample was taken in a plain sterile test tube, and kept for half an hour for clotting and then centrifuged. Supernatant clear serum was taken in two separate test tubes for the estimation of serum ferritin and serum bilirubin of the patients. For serum bilirubin estimation special precursion was taken to prevent oxidation. Data were entered in IBM PC and SPSS software (version 11.5) used to analyze data. Data were expressed as mean \pm SD. Value of the serum bilirubin compares to see the case and control by using independent sample "t" test. Difference between serum bilirubin and ferritin in two groups of thalassaemia is also compared by using the Student's "t" test. P value less than 0.05 was taken as level of significance. Serum bilirubin was correlated with serum ferritin and correlation was done by using Pearson's correlation test using the same SSPS programme.

\section{RESULTS AND OBSERVATIONS}

The observation and finding about the patients age, sex, blood group, economic status, $\mathrm{Hb}$ electrophoresis report, age of diagnosis, number of transfusion taken, state and type of chelating therapy, Hepatitis B and Hepatitis C status, Hepatitis B vaccination status and dietary habit has been observed. Prothrombin time serum bilirubin and serum ferritin were expressed as mean \pm SD.

Age - mean age of group A (case) was $8.32 \pm 5.17$ years, minimum age was 2 years and maximum age was 20 years. Mean age of the group B (control) was 7.97 \pm 4.62 years, minimum and maximum age was same as cases. Mean difference among case and control was 0.36 , p value was 0.76 (table - I). Sex - among the Group A patients 26 (65\%) were male and 14 (35\%) were female. Among the Group B 19 (66.3\%) were male and 11 (37.3\%) were female. Blood group -among Group A patients 10 (25\%) had A positive, 14 had B positive, 12 (30\%) had $O$ positive and 4 (10\%) had AB positive blood group. Hemoglobin electrophoresis report - among Group A patients $12(30 \%)$ had $\beta$-thalassaemia major and 28 (70\%) had hemoglobin E $\beta$-thalassaemia. Chelating therapy - among the Group A patients 26 (65\%) had taken chelating therapy and 14 (35\%) had not taken chelating therapy. Hepatitis B and Hepatitis C status - all of the Group A patients (100\%) were Hepatitis B and Hepatitis $C$ negative. Hepatitis $B$ vaccination status - among the Group A patients 36 (90\%) were completely vaccinated 4 $(10 \%)$ were not vaccinated. Dietary habit - among the Group A patients 39 (97.5\%) had followed the diet chart which was advised by the physicians for consumption of low iron content only 1 patient $(2.5 \%)$ had not followed 
the dietary advice. Table - II shows different general characters distribution of the thalassaemia patients.

Prothrombin time: The mean level prothrombin time in patients of thalassaemia and normal healthy children, were (13.3 \pm 1.45$)$ second and $(12.0 \pm 0.50)$ second respectively. The total mean prothrombin time was (12.79 \pm 1.29$)$. A statistically significant mean difference of prothrombin time was found indicating patients of thalassaemia had higher prothrombin time than normal healthy individuals $(p<0.001)$ (table - III). But the mean level of prothrombin time in group $A_{\text {। }}$ (patients of â thalassaemia major) was (13.83 \pm 1.33$)$ second and level of prothrombin time in group $-A_{\|}$( patients of $\mathrm{Hb} E \mathrm{~b}-$ thalassaemia) was (13.32 \pm 1.34$)$ second. A statistically insignificant mean difference of prothrombin time was found indicating group $-A_{1}$ and group $-A_{I I}$ had no difference in prothrombin time $(p>0.05)$ (table - IV). Pearson's Correlation between prothrombin time of patients in seconds and serum ferritin of in $\mathrm{ng} / \mathrm{ml}$ had studied in two ways as a whole correlation between prothrombin time of all the patients in second and serum ferritin of patients in $\mathrm{ng} / \mathrm{ml}$ had $r$ value 0.39 was statistically significant $(P<0.05)$ (table $-\mathrm{V})$. On the other side correlation between prothrombin time of the patients of group $-A_{1}$ in second and serum ferritin of same patients in $\mathrm{ng} / \mathrm{ml}$ had $\mathrm{r}$ value of 0.17 was significant $(\mathrm{P}<0.05)$. But correlation between prothrombin time of the patients of group - II in second and serum ferritin of same patients in $\mathrm{ng} / \mathrm{ml}$ had $\mathrm{r}$ value 0.46 was statistically significant $(\mathrm{P}<$ 0.05) (table - VI).

Serum Ferritin: Out of the 40 patients of Group A10 patients $(25 \%)$ had below $1001 \mathrm{ng} / \mathrm{ml}$ serum ferritin, 6 patients (15\%) had 1001 - $2000 \mathrm{ng} / \mathrm{ml}, 8$ patients (20\%) had 2001 - 3000ng/ml, 6 patients (15\%) had 3001 $4000 \mathrm{ng} / \mathrm{ml}$, and 10 patients (25\%) had more than 4001 $\mathrm{ng} / \mathrm{ml}$ serum ferritin (table - VII). Mean level of serum ferritin in the total was $(2729.40 \pm 1935.87) \mathrm{ng} / \mathrm{ml}$, minimum level was $304 \mathrm{ng} / \mathrm{ml}$ and maximum was $7256 \mathrm{ng} / \mathrm{ml}$. Mean level of serum ferritin in the patients of â - thalassaemia major was $(4098.67 \pm 1598.63) \mathrm{ng} / \mathrm{ml}$, minimum level was $1212 \mathrm{ng} / \mathrm{ml}$ and maximum was $7560 \mathrm{ng} / \mathrm{ml}$. Mean level of serum ferritin in the patients of

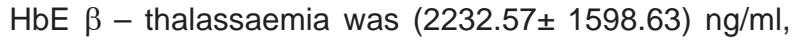
minimum level was $304 \mathrm{ng} / \mathrm{ml}$ and maximum was $630 \mathrm{ng} /$ $\mathrm{ml}$. A statistically significant mean difference of ferritin was found indicating ferritin of group $A_{1}$ (patients of $\beta-$ thalassaemia major) had higher level of ferritin than group $A_{I I}$ (patients of HbEâ - thalassaemia). ( $\left.p<0.05\right)$ (table-VIII).

Table-I

Mean age distribution of thalassaemia patients (case) and normal healthy individuals (control)

\begin{tabular}{lcccccc}
\hline Variable & Study subjects & Number & Mean \pm SD & Mean difference & $t$ & $p$ value \\
\hline Age & Case & 40 & $8.32 \pm 5.17$ & 0.36 & 0.30 & $0.76^{\text {NS }}$ \\
& Control & 30 & $7.97 \pm 4.62$ & & & \\
\hline
\end{tabular}

$P$ value reached from independent sample student's "t" test. NS= not significant $(p>0.05)$.

Table-II

Different general characters distribution of thalassaemia patients.

\begin{tabular}{llcc}
\hline Variables & & Frequency & Percentage (\%) \\
\hline Sex & Male & 26 & 65 \\
& Female & 14 & 35 \\
Blood group & A+ve & 10 & 25 \\
& B+ve & 14 & 35 \\
& O+ve & 12 & 30 \\
Type of thalassaemias & AB+ve & 04 & 10 \\
& $\beta$ thalassaemia major & 12 & 30 \\
State of chelation & Hb E thalassaemia & 28 & 70 \\
Hepatitis B vaccination status & Taken & 26 & 65 \\
& Not taken & 14 & 35 \\
Dietary advice & Vaccinated & 36 & 90 \\
& & & 10 \\
\hline
\end{tabular}


Table- III

Level of prothrombin time in seconds in case and in control.

\begin{tabular}{ccccccc}
\hline Prothrombin time in seconds & Study subjects & Number & Mean \pm SD & Mean difference & $t$ & $p$ value \\
\hline & Case & 40 & $13.30 \pm 1.45$ & 1.202 & 4.35 & $<0.001^{\mathrm{s}}$ \\
& Control & 30 & $12.10 \pm 0.50$ & & & \\
\hline
\end{tabular}

$P$ value reached from independent sample Student's "t" test. $S=$ significant $(p<0.001)$

Table-IV

Level of Prothrombin in seconds in two types of thalassaemia patients.

\begin{tabular}{ccccccr}
\hline Prothrombin time in second & Type of thalassaemia & Number & Mean \pm SD & Mean difference & $t$ & $p$ value \\
\hline$\beta$ thalassaemia major & 12 & $13.83 \pm 1.33$ & 0.51 & 1.10 & $0.275^{\mathrm{NS}}$ \\
Hb-E â thalassaemia major & 28 & $13.32 \pm 1.34$ & & & \\
\hline
\end{tabular}

$P$ value reached from Independent sample Student's "t" test. NS= non significant $(p>0.05)$.

Table-V

Pearson's Correlation between Prothrombin time of patient in second \& serum Ferritin of patient in $\mathrm{ng} / \mathrm{ml}$

\begin{tabular}{lccc}
\hline Correlation between & r value & Interpretation \\
\hline Prothrombin time of patient in second \& Serum Ferritin of patient in $\mathrm{ng} / \mathrm{ml}$ & 0.39 & Weak correlation \\
\hline
\end{tabular}

$r$ value 0.39 was statistically significant at the 0.05 level.

Table-VI

Showing difference of Pearson's Correlation between Prothrombin time of patient in second \& serum Ferritin of patient in $\mathrm{ng} / \mathrm{ml}$ in $\beta$ - thalassaemia major and $\mathrm{Hb} \mathrm{E}$ $\beta$ - thalassaemia

\begin{tabular}{lcc}
\hline Type of thalassaemia & r value & Interpretation \\
\hline$\beta$ - thalassaemia & 0.17 & No correlation \\
Hb E â- thalassaemia & 0.46 & Moderate correlation \\
\hline
\end{tabular}

Correlation is significant at the 0.05 level. Correlation between prothrombin time of patients of â- thalassaemia in second and serum ferritin of same patients in $\mathrm{ng} / \mathrm{ml}$ had $r$ value 0.17 was statistically insignificant at the 0.05 level. But correlation between prothrombin of the patients of $\mathrm{Hb} \mathrm{E} \beta$ - thalassaemia in second and serum ferritin of same patients in $\mathrm{ng} / \mathrm{ml}$ had $r$ value 0.46 was statistically significant at the 0.05 level.

\section{Table-VII}

Distribution of serum Ferritin in thalassaemia patients

\begin{tabular}{lcc}
\hline Frequency & Percentage & Ferritin level in $\mathrm{ng} / \mathrm{ml}$ \\
\hline 10 & 25 & $<1000$ \\
6 & 15 & $1000-2000$ \\
8 & 20 & $2001-3000$ \\
6 & 15 & $3001-4000$ \\
10 & 25 & $>4000$ \\
\hline Total & 40 & 100 \\
\hline
\end{tabular}

Table-VIII

Difference in serum Ferritin level between two types of thalassaemia

\begin{tabular}{llccccc}
\hline Serum Ferritin level $\mathrm{ng} / \mathrm{ml}$ & Type of thalassaemia & Number & Mean \pm SD & Mean difference & $\mathrm{t}$ & $\mathrm{p}$ value \\
\hline & $\beta$ thalassaemia major & 12 & $4098.67 \pm 2086.83$ & 1866.0 & 3.08 & .004 \\
& Hb-E â thalassaemia major & 28 & $2232.57 \pm 1598.62$ & & & \\
\hline
\end{tabular}

$P$ value reached from Independent sample Student's " $t$ " test. Significant $(p<0.05)$. 


\section{DISCUSSION}

Beta thalassaemia major and $\mathrm{Hb}-\mathrm{E}$ Beta thalassaemia is common in our country. The thalassaemia patient develops liver fibrosis as a result of iron overload due to excessive blood transfusion and also from excess intestinal absorption. In recognizing the hepatotoxic potentials of iron over load the cross sectional comparative study had been under taken to find the state of liver function in the thalassaemia patients. In addition serum ferritin level also had been determined in the patients to find the relation of serum ferritin with liver function test.

In this study $30 \%$ patients had $\beta$ - thalassaemia major and $70 \%$ patients had $\mathrm{Hb}-\mathrm{E} \beta$ - thalassaemia, these finding showed that second groups of patients were more than double of first one. This finding was not in accordance with Purnamawati et $\mathrm{al}^{19}$. They had studied on more number of $\beta$ - thalassaemia major patients. Chelation therapy was taken $65 \%$ and $35 \%$ was not taken chelation therapy. This finding revealed that about two third of the patients were alert about their iron overload and were taking the proper management, this finding also is not consisted with Purnawati et $\mathrm{al}^{19}$. They were studied on irregularly chelated patients. Hepatitis B and Hepatitis C patients were $100 \%$ negative, actually during collection of sample from the patients 1 Hepatitis $C$ positive patient was found he had excluded from the study in order to avoid possibility of undue influence on liver function. Regarding Hepatitis B vaccination 90\% were completely vaccinated $10 \%$ were not vaccinated. This finding pointed that most of the patients were conscious that they might be infected through blood transfusion and had taken necessary action. The diet chart which was advised by the physicians for consumption of low iron content had followed $97.5 \%$ and had not followed only $2.5 \%$. This finding again revealed that the patients and their parents were very much concern about their disease and as per direction of the physicians they have taken proper steps.

In order to assess the state of liver function the most sensitive liver function test Prothrombin time was done. The mean level Prothrombin time in patient of thalassaemia and normal healthy children were $13.3 \pm 1.45$ second and $12.0 \pm 0.50$ second respectively. The total mean Prothrombin time was 12.79 \pm 1.29 second. A statistically significant mean difference of Prothrombin time was found indicating patient of thalassaemia had higher Prothrombin time than normal healthy children $(p<0.001)$. But mean Prothrombin level in thalassaemia child was only mildly increased when upper limit of mean was considered. The difference between mean levels of Prothrombin time of the patients of $b$-thalassaemia major and $\mathrm{Hb} \mathrm{E}$ b-thalassaemia was statistically insignificant. The mean levels were $13.83 \pm 1.33$ second and $13.32 \pm 1.34$ second respectively. The finding reveals that Prothrombin time in two type of thalassaemia are similar. Pearson's Correlation between Prothrombin time of patients in seconds and serum ferritin of patient in $\mathrm{ng} / \mathrm{ml}$ had studied in two ways as a whole correlation between Prothrombin time of all the patients in second and serum ferritin of patient in ng/ $\mathrm{ml}$ had $\mathrm{r}$ value 0.39 was statistically significant $(P<0.05)$. This finding is consistent with the study by Naithani et al. On the other side correlation between Prothrombin time of the patients of $b$-thalassaemia major in second and serum ferritin of same patients in $\mathrm{ng} / \mathrm{ml}$ had $\mathrm{r}$ value 0.17 was statistically insignificant. But correlation between prothrombin time of patients of $\mathrm{Hb} \mathrm{E}$ â-thalassaemia in second and serum ferritin of same patients in $\mathrm{ng} / \mathrm{ml}$ had $r$ value 0.46 was statistically significant $(P<0.05)$. From this finding it can be interpreted that in $\mathrm{Hb} \mathrm{E}$ âthalassaemia, serum ferritin level is correlated with prothrombin time.

\section{CONCLUSION}

Iron over load is very common in thalassaemia patients and it is one of the important cause to interfere the liver function. So in this study a sensitive liver function test prothrombin time was correlated with serum ferritin. Increased level of serum ferritin was found in $100 \%$ of study subjects. Prothrombin time was increased than normal subjects but here minimal change occurs. Prothrombin time is correlated with serum ferritin level in $\mathrm{Hb}$ E $\beta$-thalassaemia but not â-thalassaemia major. However prolong prothrombin time is not a specific test for liver disease, for confirmation other liver function tests are essential.

\section{REFERENCES}

1. Weatherall DJ, Clegg JB, Thalassaemia - a global public health problem. Nat Med, 1996:2,847-9.

2. Firkin F, Chesterman C, Penington D, Rush B.(eds)1996, de Gruchy,s Clinical Hematology in Medical Practice. $5^{\text {th }}$ ed, Blackwell, Australia,137.

3. Olivieri NF, Weatherall DJ. Recent progress in the Management of thalassaemia. HKJ Paediatr (New series) 1996; 1: 14-22.

4. Higgs DR, Thein SL, Woods WG. The molecular pathology of Thalassaemia. In: Weatherall DJ, Clegg B, eds. The Thalassaemia syndromes. $4^{\text {th }}$ ed. Oxford, England: Blackwell science, 2001: 133-91.

5. Lehmann H, Carrell RW. Differences between alpha and beta chain mutants of human hemoglobin and between alpha and beta thalassaemia. Possible duplication of alpha chain gene. Br. Med J 1968; 4: 748-50. 
6. Hoffbrand AV, Cohen A, Hershko C. Role of deferiprone in chelation therapy for transfusion iron overload. Blood 2003; 102: 17-24.

7. Olivieri NF. The beta thalassaemias. N Engl J Med 1999; 341: 99-109.

8. $\quad \mathrm{WHO}$ guideline for the Hemoglobin Disorders. Unpublished document WHO/HDP/HB/GL/94. Obtained free of charge from the hereditary Disease Programme. WHO, Geneva, Switzerland.

9. Khan WA, Banu B, Amin SK et al. prevalence of beta thalassaemia trait and HB-E trait in Bangladeshi school children and health burden of thalassaemia in our population. 2005; 21: 1-7.

10. Voskaridou E, Douskou M, Terpose E, et al. magnetic resonance imaging in the evaluation of iron overload in patients with $\mathrm{a}$ - thalassaemia and sickle cell disease. $\mathrm{Br}$ J Haematol 2004; 126: 736-42.

11. Papanikolaou G, Tzilianos M, Christakis JI, et al. Hepcidin in iron overload disorders. Blood 2005; 105: 4103 - 5 .

12. Hershko C, Konijn AM, Link G. Iron chelators for thalassaemia. Br J Haematol 1998; 101: 399-406.
13. Olivieri NF, Brittenham Gm: Iron- chelating therapy and the treatment of thalassaemia. Blood 1997; 89: 739.

14. Nelson R, Chawla M, Connolly P, Laporte J. Ferritin as an index of bone marrow iron store. South Med J 1978; 71 : 1482-84.

15. Valberg LS. Plasma ferritin concentration, its clinical significance and relevance to patients care. Can Med Assoc J 1980; 122: 1240-48.

16. Jabobs A, Worwood M. Serum ferritin concentration in health and disease. N Eng J Med 1975; 292: 951 - 2.

17. Jacobs A, Miller F, Worwood M. Ferritin in serum in normal subjects and patients with iron deficiency and iron overload. Br Med J 1972; 4: 206 - 208.

18. Lipschitz DA, Cook JD, Finch Ca. Aclinical evaluation of sewrum ferritin as an index of iron store. $\mathrm{N}$ Eng $\mathrm{J}$ Med 1974; 290: 1213 - 1216.

19. Purnamawati SP, Pamella K, IMral C, Julfina B, Hanifah O. Profile of alanine aminotransferase and hepatic accumulation in thalassaemia patients with or without antihepatitis C virus. Paedriatica Indonesiana 2004; 44: 85 -88 . 